\title{
The Comparison of the Position of Human Rights in Liberalism Theory and English School of International Relations
}

\author{
Hojat Garaee \\ Department of Political Sciences, Ilam Science and Research Branch, Islamic Azad University, Ilam, Iran \\ Jahanbakhsh Moradi \\ PhD of International Relations, Faculty Member of the Department of Political Science, \\ Ilam Branch, Islamic Azad University, Ilam, Iran \\ Email: Jmoradi7877@yahoo.com
}

\author{
Doi:10.5901/mjss.2016.v7n3s3p371
}

\section{Abstract}

Distress of human rights expansion entered the era of international relations and foreign policy of countries as a debate in international dimensions after World War II. Global declaration of human rights and all mechanisms of United Nations practically highlighted the globalization of human rights. After cold war and the emergence of new international system, many capabilities generated for international cooperation in the field of expansion of human rights idea. In addition, foreign policy of countries dealt with this matter. In this direction, Liberalism and English school are very important. English school believes that international societies of governments are not immoral units and are represented by individuals that inevitably have moral stance. International society based on moral principles. These principles to pluralist branch of school include a kind of minor morals i.e. in the form of agreement among governments regarding principles that provide the possibility of coexistence and cooperation in the direction of common interests. These principles to solidarity-oriented branch include rich ethics i.e. universal moral principles such as supporting human rights. In contrast, Liberalism theories believe according to this fact that society should lack external pressure and obligation, they clearly remind a unique position in human rights. They try to normalize realist world and develop human rights at international level for example, humanism intrusion largely implies international liberal though against governments sovereignty and the establishment of liberal order in the world.

Keywords: Liberalism, English school, human rights, international society, ethics

\section{Definition of human rights}

There are many definitions for human rights. For example, the rights that particularly belong to every person and are related to human nature and essence. Human right means general advantages that every person possesses. Human rights based on the nature of every human being. Perhaps it can be said that human rights are radical and basic rights that every human being has received from god regardless of race, language, nationality, geography, social variable conditions and the extent of personal competence and capability (Baqerzadeh, 2005, 5). The definition are not comprehensive i.e. while human rights should lack any condition and constraint for human beings since they are human, shouldn't be depended on conditions and imposition of constraints because humanist human rights distinguish rights for human apart from nature characteristics. While human rights with religious source based on rights with divine source. Therefore, we can say that human rights with humanist source have not universal capability in many cases. Then, the reason of noted definitions' difference is different attitudes that result from human rights foundations (Javid et al, 2012, 83).

\section{The position of human rights in international system from beginning to now}

\subsection{First stage: normative basis}

First stage of this process began by enforcement of charter and continued by acceptance of international covenants of 1996 human rights. Global declaration of human rights that accepted by UN such as the acceptance of massacre treaty and treaty of elimination of all forms of ethane discrimination only notes main tools of human rights. During this period, 
European covenant of human rights was imperative. Organization of American governments issued American declaration of human rights. UNESCO and international labor organization (ILO) respectively issued concords against discrimination in education, and discrimination in job and employment, generally this period shows normative consolidation of rules of international human rights. Of course, noted process continues to present time.

Nevertheless, this process is exceptional in the first 20 years after the establishment of United Nations. There are two important factors in this evolution. First, regulations of human rights in the charter of UN that are completed by global declaration of human rights and other documents of human rights should be considered as determination of main commitments of human rights that member states have accepted Via ratification of united Nations charter (UNC). In other words, while many states in the early days of establishment of UN noted that charter has not imposed any obligation on them in the field of human rights, this problem statement was no longer acceptable in the end of 1960s. Second, when it was accepted that charter has generated some commitments for member states as a multi- Lateral treaty in the field of human rights was considered as a subject of international rights to the extent that human rights became international (Boergental, 2000, 22-3).

\subsection{Second stage: institutionalization}

Second stage in the evolution of rules of international human rights began in the end of 1960s and continued 20 years later. This time is historical source of institutionalization. During these years, we saw two distinctive changes in the framework of UN: first change related to the mature or area of commitments of human rights that imposes articles 55(3) and 36 of charter on member states of UN. When this problem was resolved, UN could generate bodies and mechanisms for enforcement of states' commitments. In a legal perspective, response to the problem of commitments of member states means "encouragement of human rights respect and basic freedoms" (Kiani, 2006, 156).

Certainly, we can say that this restriction did not bind states to stop all violations of human rights in the time of joining United Nations charter. Above restriction was very ambiguous for this purpose. Even in that how much and to what extent state can continue the violations of human rights before joining charter?

Are there some violations of human rights that should stop? It takes a long time for UN to answer these questions clearly. Some regulations gradually enacted and developed outside UN system to end apartheid. Apartheids can be regard as a comprehensive violation of all basic human rights and as a governmental policy that will exercise against a large part of population. However, in this field the meaning of "encouragement" commitment despite its general and abstract ambiguity will express in objective concept that a member of UN that has adopted such a policy or continued such a strategy cannot be among states that encourage human rights and basic freedoms. Therefore, it violated the obligations of charter (Kiani, 2006, 156).

\subsection{Third stage: enforcement of human rights after cold war}

Noted bodies in previous section have not been active completely. They could begin effective performances toward guarantee of enforcement of state's international obligation in the mid of 1908s. The establishment of international bodies for expanding and supporting human rights is one matter, and providing tools and capabilities for achieving their purpose is another matter. When states and their allies are accused of human rights violation, mainly they are agree with the establishment of human rights bodies to cooperate with these bodies. Therefore, we should accept that these effective political factors in the big attempt of establishment of human rights bodies have increasingly caused that states do not behave according to their human rights obligations face more problems. In this period, world experienced significant changes and evolutions that significantly helped the evolution of human rights. Noted evolution has significantly been profitable.

In the end of cold war, many European nations escaped from communism domination and allowed to attempt democratic transition process. In addition, international actions regarding human rights extension escaped from weakening ideological disputes and past political slogans.

These changes have allowed UN to concentrate on barriers of human rights enforcement (Boergental, 2000, 98).

The end of cold war and its impacts on human rights reflected in a part of Vienna 1993 declaration about human rights.

Comprehensive area of this declaration shows that at least most of the new subjects of human rights have considered. One of the interesting features is that Vienna declaration has been expressed in balanced and serious political style. While this declaration has not presented solutions for many severe problems that international, society faces them. However, it determines a few subjects in this process that have not considered at international level. This 
includes the following rights: socio- cultural rights, political and civil rights, devilment right, asylum rights and individuals who are homeless inside the country, minority rights and native people, women rights and children rights (Boergental, 2000, 98-9).

\section{The position of human rights in Liberalism theories}

Liberalist thought does not consider human rights as a marginal issue, but considers it as a new mechanism in international relations.

They believe current criteria of human rights influence the change and kind of governing regimes. David Foresight believes that we should consider the understanding of human rights in international attitudes as a paradigm. Liberalists consider defending human rights as defending natural claims of human beings. Modern Liberalism hypothesis about human rights transferred from complex language of middle Ages regarding rights to modern periods. In other words, human rights in modernist era were developed.

Liberalists believe that the principle of nation is origin of sovereignty. This is against the hypothesis of realist sovereignty (Mosafa \& Ibrahimi, 2008, 265).

In 1815 Vienna congress, super powers accepted to stop slave trade. Finally, Brussels convention abolished slave trade in 1980. In addition, the goals of Hague convention that approved in 1907 and 1926 Geneva Convention were to integrate humanitarian considerations and develop protection of human rights Limits. Generally, Liberalists have become one of the main supporters of above thought in the middle of $20^{\text {th }}$ century to develop their thought about human rights. Today all have accepted this principle that nobody should face cruel or degrading treatment and punishments (article 5 of global declaration of human rights, article 7 of treaty of civil- political rights, article 3 of European convention of human rights and section of human rights) (Mosafa \& Ibrahimi, 2008, 265).

The position of human rights in Liberalism theory of international relations focused on moral theory of Emanuel Kant. He believes Moral actors obligate practical wisdom to accept moral principle of human rights. However, Kant believes the stability of states is dependent on democratic rule of low that can express freedom and independence, but it is very important to enjoy peaceful order of state- nation based on self- consciousness and understanding of primary rights of human beings.

There are differences in traditional and modern Liberalism about the role of state in the development of human rights. In traditional Liberalism, personal area is autonomy domain and non-intrusion of state since there primary core and member of right is personal ownership, and government is considered as a destructive and anti- human rights element. However, in modern Liberalism, we require active presence of state to support suitable conditions for real freedom of human beings but role of state is limited. Indeed, state plays the role of a cooperator or assistant (Moshirzadeh, 2008, 296).

Now we consider the relationship between order and human rights in Liberalism theory about the position of human rights. Liberalist interprets the concept of order in the framework of Liberal global order. George Sorenson in his article "what kind of global order?" believes however, we might define global order as dominant orders among states but we consider global order as an order that has been established by liberal values. Sorenson believes that Liberal values have summarized in the documents of UN. These values include freedom, accountability, social justice and equal opportunities. These value should happen and states should adapt themselves with these values so that Liberal global order to be established. He notes, "We believe that civil society and democracy occur when economy is based on the rules of free market, fair distribution of wealth and resources and encouragement to innovation" (Moshirzadeh, 2008, 309).

Liberalists consider Liberal global order in the framework of international rights, respect to human rights, respect to minority and religions rights and economic development.

Theory of Liberal international relations emphasizes the priority of internal resources of state. This trend reveals differences between institutional neoliberals and new realism based on state- focused attitude in international system. Institutional neoliberals believe that states have interests for entering international institutional orders that prevent inappropriate actions and unwanted consequences. Human rights violence's rarely appear in classic puzzle of mutual dependence. Therefore, we can consider cooperation in the area of human rights from institutional neoliberal's perspective. In this respect liberal theory of international relations concentrates on internal preferences or attitudes about society of Liberal states, and tries to achieve more useful and efficient peace and democracy in the study of human rights (Mosafa \& Ibrahimi, 2008, 267).

Moraweski is one of the Liberal theorists that discuss Liberal attitudes. Te believes that states accept human rights treaties as the tools of political survival and implement them against nondemocratic states. He believes that 
establishment of international human rights bodies is a logical movement but these obligations and human rights enforcement are voluntary for Liberal state in Liberalism theory.

Realists believe that these obligations and human rights enforcement are compulsory. International relations Liberalism distinguishes independent and limited role for international organizations to develop common norms and cooperation.

However, such claims mainly are meaningful in the bed of Liberal society of states (Mosafa \& Ibrahimi, 2008, 267).

\section{The position of human rights in English school}

English school that discussed in the late of 1950s and early of 1960s is an institutional and historical approach towards policy world. It concentrates on human beings and their political values. English school includes legal and political mechanisms of international society to promote the rules of human rights. Therefore, some assumptions of tradition of international society are as follows:

-International relations is a branch of human relations that values such as independence, security, order and justice are its main components.

- It is a human- focused approach. Researcher of international relations interprets the actions and attitudes of individuals who are involved in international relations.

- It accepts anarchy in international relations, but researchers of international society believe that policy world is an anarchist society with discrete rules, norms and bodies that politicians apply in the implementation of foreign policy (Jackson \& Sorenson, 2010, 181).

English school called state- focused

Since emphasizes society of states. Writers such as white and Bull clearly emphasize governmental actors, but in cases that writers of English school have exhibited more solidarity-oriented inclinations including recent works of Bull or wisents we can see their attention to human as the subject of international relations. In other words, in cases that discussion has shifted from society of states to global society particularly in discussion about human rights we can see such an inclination in English school. Of course, sometimes according to this fact that in discussion about human rights, focus is a society that consists of states and their duty perhaps this inference is not correct (Moshirzadeh, 2008, 175-6).

Solidarity oriented approach of English school unlike pluralism considers relational responsibilities and the necessity of intervention to promote human justice. In other words, in the case of real defect of human rights humanitarian interventions made via resorting to force, presenting humanitarian aids and crisis management activities by international organizations. For example, relational attempts that made by Security Council in former Yugoslavia war were a mixture of limited humanitarian intervention to support non- militants, presenting humanitarian aids and achieving desirable conditions via negotiation (Jackson \& Sorenson, 2010, 2008). Security Council in Libya issue during changes of Arabian spring approved 1927 resolution that was a reactional attempt to enforce "support responsibility" (Mosafa \& Shams Lahijani, 2012, 2). Libya case shows that support responsibility doctrine in new international law has considered sovereignty of countries as a punitive issue. Therefore, it rejects ineffective sovereignties that violate the rights of citizen.

\section{Conclusion}

Based on modernist interpretations of Liberalism, it assumed Liberalism political systems that are gradually developing have established based on mere scientific and nonreligious attitudes. However, a part of this imagination in adoption of "scientific attitudes" seems correct but ignoring religious messages in the foundation of Liberalism industry is a big neglect in understanding the manner and reason of Liberalism globalization.

We can attribute the reason of such neglect in identification of foundations to interaction via modernism and west capitalism and gradual extension of Christianity.

Discussion is not about goodness and heinousness of this wave and unsuitable extension of Christianity, but important point is paying attention to Justifiability of Liberalism movement for sovereignty that gradually occurred after trade and industrial revolution in west, and continues up to now. Liberalism believes that nonviolent discussion with nations is not very difficult. Indeed, both Liberalism and nationalism have passed an interrelated area for globalization. In other words, we can say that during 300 years evaluation process of Luck political thought, Liberalism and nationalism have been two inseparable elements of globalization area. Since both Liberalism and nationalism have begun from rational foundations, they had to get along with each other for globalization despite their discrepancies, but they have common stance regarding the thought of maintaining peace, security of life and wealth, and freedom.

On the other hand, however English school has one of the most advanced theoretical premises to promote the 
rules of human rights and prevent violation of humanitarian international rights, but this approach has weakness for determining the doctrine of support responsibility. One of the main weaknesses of English school for determining the doctrine of support responsibility is inattention to issue of distributive Justice in international society. Therefore, distributive Justice in international society is concerned with decreasing the gap of north and south countries, suitable distribution of opportunities and primary rights of human beings such as tenure opportunities, amenities, and pharmaceutical equipment. It prevents the violation of human rights in the doctrine of support responsibility. Hedley Bull believes that distributive justice should consider more as an issue of internal policy than international policy. Therefore, it is in the second rank of importance. This viewpoint of Bull has risen in conditions that in globalization era of human rights distributive justice should attract more attention of international relations.

\section{References}

Baqerzadeh, Ali (2005). Structural change of Liberalism and Cconcept of Human Rights, Strategy Periodicals, № 21.

Boergental, Tomas (2000). Structural and Normative Change of International Human Rights, Translated by Hossain Sharifi Taraz Koohi, Strategy Periodicals, № 18.

Jackson, Robert \& Sorenson, George. (2010). An Introduction to International Relations, Translated by Mahdi Zakerian et al, Tehran, Mizan Press.

Javid, Hossein (2011). Human Rights (Theories and Procedures), Tehran: Tehran University

Kiani, Davoud (2006). Internationalization of Human Rights and Metamorphosis in the Concept of States' Sovereignty in Globalization Era, Islamic Human Rights Periodicals, First Year, No1.

Mosafa, Nasrin \& Ibrahimi. Ali Reza (2008). Libya, Responsibility Arena for Support, Strategic Studies Periodicals, $15^{\text {th }}$ Edition, No 55.

Mosafa, Nasrin \& Shams Lahijani. Ali Reza (2012). Libya, Responsibility Arena for Support, Strategic Studies Periodicals, 15 ${ }^{\text {th }}$ Edition, No 55 .

Moshirzadeh, Homaira \& Ibrahimi. Mohammad (2008). Foundations of Human Rights in International System, Forogh Periodicals, № 4. 